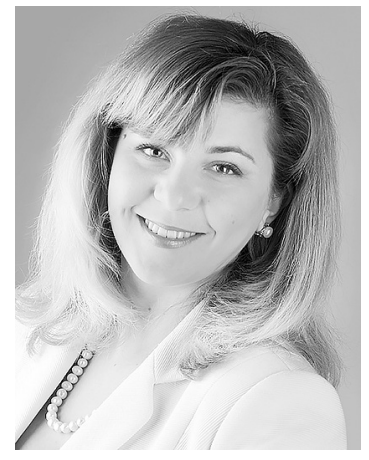

\title{
ПРОБЛЕМА ЗАХИСТУ ЗАКОННИХ ІНТЕРЕСІВ ГРОМАДЯН УКРАЇНИ У СФЕРІ ВЛАСНОСТІ ЗАСОБАМИ АДМІНІСТРАТИВНОГО ПРАВА
}

професор, завідувач кафедри цивільного права та процесу, Навчально-науковий інститут права, психології та інноваційної освіти Національного університету «Јьвівська політехніка"

https://orcid.org/0000-0002-4838-3579

DOI 10.32782/NP.2021.4.4

Статья посвящена анализу законньхх интересов граждан Украинъ в сбере собственности, специбики защить средствами административного права, поиска путей формирования системъ вфббективньхх средств административно-правовой защитъи этих правовых возможностей граждан, осуществления правовых реборм в этой сфере. Особое внимание уделено обоснованию правовой природъг категории «законнъий интерес», административно-правовъгх способов и средств его защитьл. Получил дальнейшее развитие анализ деятельности субъектов защиты законных интересов граждан в сбере собственности, спеиибики публичного управления в этой сфере, формирование эбббективной законодательной модели административно-правового регулирования общественных отношений в сфере защить правовых возможностей граждан по владению, пользованию и распоряжению имуществом.

Ключевъе слова: законнъий интерес, право, административно-правовое средство, право собственности, защита законных интересов граждан в сбере собственности, органы публичного управления, административная ответственность.

Вступ

Проблема захисту законних інтересів громадян України у сфері власності засобами адміністративного права має багато- аспектний характер та важливе теоретичне і прикладне значення. Законний інтерес є специфічним феноменом правового життя сучасного суспільства. Усе більшого значення набуває пошук шляхів формування системи ефективних засобів адміністративно-правового захисту цих правових можливостей громадян, здійснення правових реформ щодо цього.

\section{Постановка проблеми}

Адміністративне законодавство відіграє ключову роль у забезпеченні захисту законних інтересів громадян України. Його норми $є$ субстанційними засобами захисту правових можливостей особи щодо володіння, користування та розпорядження майном. Вони регулюють відносини між громадянами і суб'єктами публічного управління, громадськими формуваннями стосовно реалізації законних інтересів громадян у сфері власності, протидії посяганням на майно, відновлення порушених внаслідок незаконних рішень, дій чи бездіяльності суб'єктів владних повноважень законних інтересів громадян щодо володіння, користування та розпорядження майном.

Формування ефективних пропозицій щодо забезпечення адміністративноправового регулювання відносин у сфері власності, створення адміністративноправового фундаменту оптимізації захисту 
правових можливостей громадян щодо володіння, користування та розпорядження майном та вирішення проблем правозастосовної практики у цій сфері пов'язане 3 проведенням грунтовного наукового аналізу сучасної системи адміністративноправових засобів захисту законних інтересів громадян України у сфері власності.

\section{Стан дослідження проблеми}

Теоретичну основу дослідження формують результатів наукової роботи вітчизняних учених: Д. Бахраха, В. Галунька, О. Малька, О. Остапенка, Т. Підлубної, В. Рубаника, А. Шерієва та інших.

Водночас наявні дослідження не достатні для розв'язання теоретичних i практичних проблем захисту законних інтересів громадян України у сфері власності засобами адміністративного права.

Метою статті $є$ науковий аналіз проблеми адміністративно-правового захисту законних інтересів громадян у сфері власності засобами адміністративного права.

Наукова новизна статті проявляється в тому, що в роботі здійснено комплексний аналіз проблеми захисту законних інтересів громадян у сфері власності. Особлива увага присвячена обгрунтуванню правової природи категорії «законний інтерес», адміністративно-правових способів та засобів його захисту. Дістав подальший розвиток аналіз діяльності суб'єктів захисту законних інтересів громадян у сфері власності, виявлення специфіки публічного управління у цій сфері, формування ефективної законодавчої моделі адміністративно-правового регулювання суспільних відносин у сфері захисту правових можливостей громадян щодо володіння, користування та розпорядження майном.

\section{Виклад основного матеріалу}

Сучасне науково-теоретичне обгрунтування змісту категорії «законний інтерес» віддзеркалює багатовікові зусилля філософів та юристів щодо осмислення їі суті, тривалі наукові пошуки ефективних засобів захисту законних інтересів громадян.
Спроби висвітлення цих питань знаходимо в численних працях, присвячених проблемам захисту правових можливостей осіб у сфері власності, проте вони не містять комплексного дослідження категорії законного інтересу громадян у сфері власності, не визначають засобів адміністративного права, спрямованих на їх захист, не відображають систему сучасного дослідницького інструментарію юридичної науки, який здатен забезпечити глибокий та системний розгляд досліджуваних питань.

Урахування надбання юридичної науки, дослідження теоретичних та практичних аспектів захисту засобами адміністративного права законних інтересів громадян України щодо володіння, користування та розпорядження майном є надійною основою вирішення проблем та пошуку ефективних адміністративно-правових засобів захисту законних інтересів громадян України у сфері власності.

Слід визнати той факт, що законний інтерес громадян у сфері власності породжується потребами громадян щодо володіння, користування та розпорядження майном. Він завжди знаходить свій прояв у відносинах, інтелектуально-вольовій практичній діяльності соціального суб'єкта, відбиває сформовану у свідомості, притаманну менталітету цілу систему цінностей. Законні інтереси є основою виникнення суб'єктивних прав. Вони здатні трансформовуватися у суб'єктивні права у випадку їх соціальної значущості та типовості для суспільства. Слід погодитися 3 думкою, що інтереси мають значення для права як об'єктивні соціальні детермінанти, які відображають ті ж закони суспільства [1, с. 34-41].

Законні інтереси у сфері власності тісно пов'язані 3 суб'єктивним правом щодо володіння, користування та розпорядження майном, існують як його першооснова, розширюють коло можливої поведінки особи 3 приводу матеріальних благ. Суб'єктивне право та юридичний обов’язок виступають специфічними формами реалізації інтересів особи у сфері власності. 


\section{Адміністративне право}

Законні інтереси громадян у сфері власності зумовлені різними моральними та економіко-соціальними детермінантами: майновим становищем, вихованням, моральними якостями, психофізичними особливостями організму та іншим. Під впливом цих детермінант кожна людина визначає власну систему потреб та на їх основі формує індивідуальний законний інтерес у сфері власності.

Державні законні інтереси у сфері власності відображають волю переважної більшості суспільства, акумулюють у собі сукупність законних інтересів окремих громадян, забезпечених системою правових засобів, є проявом державної законодавчо оформленої волі.

У правовій державі під впливом державної волі найбільш вагомі законні інтереси громадян у сфері власності, які відображають головні потреби суспільства, здатні трансформуватися у державні законні інтереси.

Можна стверджувати, що формування ефективної законодавчої моделі адміністративно-правового регулювання суспільних відносин у сфері захисту правових можливостей громадян щодо володіння, користування та розпорядження майном пов'язано з розв'язанням низки нагальних проблем: удосконаленням норм КУпАП, який визначає основні види адміністративних проступків у сфері власності; закріпленням ефективної системи заходів попередження, виявлення, припинення та розслідування правопорушень у сфері власності; покращенням правового забезпечення кваліфікації адміністративних проступків у сфері власності, відшкодування винним майнової шкоди; визначення дієвих способів захисту законних інтересів власників об'єктів інтелектуальної власності, що використовуються у всесвітній мережі Інтернет; законодавчим закріпленням правових засобів гарантування реалізації громадянином права власності на одержані доходи тощо.

Конституційний Суд України у своєму рішенні зазначив, що, виходячи зі змісту частини першої статті 8 Конституції України, охоронюваний законом інтерес перебуває під захистом не тільки закону, а й об'єктивного права у цілому, що панує у суспільстві, зокрема справедливості, оскільки інтерес у вузькому розумінні зумовлюеться загальним змістом такого права і $є$ його складовою [2].

У науковій літературі цілком слушно було сформовано твердження, що зміст законного інтересу зводиться до чотирьох основних аспектів: 1) існування інтересу, який немислимий без того, щоби суб'єкт правовідносин не прагнув володіти благом, яке здатне задовольнити його потреби; 2) прагнення до володіння зазначеним благом повинно відповідати сучасним нормативним приписам, змісту законодавства; 3) благо, до якого прагне суб'єкт, не повинно бути протиправним, інакше інтерес позбавляється «рангу» законного (у цьому разі можна говорити про інтерес, який має юридичний характер, але протиправний за своєю суттю); 4) незважаючи на те, що особа, яка володіє законним інтересом, не може вимагати поведінки, яка його не порушує, від інших осіб, що й відрізняє інтерес від суб'єктивного права, законний інтерес - самостійний об'єкт правової охорони і захисту [3, с. 20].

Держава гарантує громадянам можливість власними діями здійснювати захист законних інтересів у сфері власності та забезпечує функціонування системи органів влади, діяльність яких спрямована на захист прав та законних інтересів громадян України у сфері власності. Вони реалізують свій адміністративно-правовий статус в управлінському, адміністративному процесі, у процесі застосування заходів адміністративного примусу для припинення адміністративних правопорушень у сфері власності, відновлення порушених законних інтересів тощо.

Основними органами публічного управління у цій сфері виступають органи виконавчої влади та місцевого самоврядування. Правове становище органу публічного управління в системі суб'єктів захисту законних інтересів громадян у сфері власності зумовлене його місцем у цій системі, змістом компетенції, організаційно-правовою формою, цілями утворен- 
ня, порядком прийняття управлінських рішень, територіальним масштабом його діяльності тощо. Діяльність правоохоронних органів проявляється у практичній роботі з приводу попередження, припинення адміністративними засобами посягань на гарантовані законом можливості громадян щодо володіння, користування, розпорядження майном та притягнення до адміністративної відповідальності за адміністративні правопорушення у сфері власності. Відповідними повноваженнями наділені органи внутрішніх справ, СБУ, прокуратура, судові органи.

Визначальним напрямом діяльності органів влади як суб'єктів захисту законних інтересів громадян України у сфері власності є реалізація адміністративноюрисдикційних повноважень.

Справи про адміністративні правопорушення у сфері власності розглядають посадові особи спеціально уповноваженого центрального органу виконавчої влади у галузі екології та природних ресурсів України (ст. 242-1 КУпАП), органів виконавчої влади у сфері захисту прав споживачів (ст. 244-4 КУпАП), органів внутрішніх справ (ст. 222 КУпАП), адміністративних комісій при виконавчих органах міських рад (ст. 218 КУпАП), Національного банку України (ст. 234-3 КУпАП), судові органи (ст. 221 КУпАП) та інших суб'єктів владних повноважень.

Основною ознакою способів адміністративно-правового захисту законних інтересів громадян у сфері власності $\epsilon$ їх чітка законодавча регламентація. Ці способи захисту знайшли своє відображення у нормативно-правових актах - Кодексі України про адміністративні правопорушення, Кодексі адміністративного судочинства України, законах та підзаконних нормативно-правових актах.

Зовнішнім проявом способів адміністративно-правового захисту законних інтересів громадян у сфері власності є закріплені у нормативно-правових актах процедури. Ці процедури регулюють дозволені в державі заходи щодо захисту законних інтересів громадян у сфері власності та стосуються порядку встановлення фак- ту вчинення неправомірного посягання на законні інтереси громадян, здійснення юридично-значущих дій щодо припинення протиправної поведінки у цій сфері, притягнення винних до відповідальності, відшкодування заподіяної шкоди, видання адміністративних актів щодо задоволення потреб громадян у сфері власності, визнання повністю або частково недійсними (нечинними) рішень державних органів, зобов'язання органу влади вчинити певні дії з метою забезпечення реалізації законних інтересів громадян чи їх відновлення, здійснення організаційних заходів та матеріально-технічних операцій 3 цього приводу тощо.

Окрім системи способів захисту законних інтересів громадян, до механізму адміністративно-правового захисту законних інтересів громадян у сфері власності належить система засобів захисту у цій сфері.

До засобів адміністративно-правового захисту законних інтересів громадян у сфері власності можна віднести систему засобів-інструментів (зокрема нормативно-правових актів, які забезпечують недоторканість майнових прав у сфері власності, цілісність об'єкта права власності, що регулюють порядок відновлення законних інтересів власників у разі їх порушення), засобів державно-юридичної захисної діяльності, які здійснюються юрисдикційними органами, судами та органами адміністративної юстиції; засобів самозахисту, що проявляються через здійснення юридично значущої захисної діяльності громадян.

3 огляду на інструментальний підхід, юридичними засобами захисту правових можливостей людини є ті юридичні явища, використання яких у правозахисній діяльності має забезпечити задоволення потреби людини у захисті [4, с. 15]. До них відносять систему субстанційних та діяльнісних феноменів правового характеру [5, с. 15$]$.

Система засобів адміністративно-правового захисту законних інтересів громадян у сфері власності охоплює два типи правових явищ: 1) матеріальні та проце- 


\section{Адміністративне право}

суальні адміністративно-правові норми, що стосуються попередження, припинення порушень прав та законних інтересів громадян у сфері власності, відновлення правових можливостей володіти, користуватися та розпоряджатися майном, притягнення винної особи до відповідальності, нормативні юридичні акти у цій сфері; 2) діяльнісні засоби захисту, що можуть набувати форму документованих дій (позовів, скарг, заяв, клопотань, рішень, постанов) чи фактичних дій (явка в судове засідання, затримання особи, яка вчинила адміністративний проступок у сфері власності, тощо).

Засоби адміністративно-правового захисту відображають практичну сторону юридичних процедур, забезпечують реальне вирішення проблемних питань, що стосуються законних інтересів громадян володіти, користуватися та розпоряджатися майном, та сприяють забезпеченню реалізації потреб, пов'язаних із набуттям та збереженням об'єктів права власності.

За своїми функціями засоби адміністративно-правового захисту законних інтересів громадян у сфері власності можуть бути матеріальними (положення ст.13 Конституції України, у якій безпосередньо міститься вказівка щодо забезпечення державою захисту всіх суб'єктів права власності) та процесуальними (адміністративний позов щодо визнання нечинним рішення суб'єкта владних повноважень у сфері власності).

Засоби адміністративної відповідальності виступають у вигляді певних обмежень та заборон, спрямованих на забезпечення порядку володіння, користування та розпорядження майном та покарання особи, яка своїми діями посягає на законні інтереси громадян у сфері власності.

Такі обмеження i заборони можуть стосуватися дрібного викрадення чужого майна (ст. 51 КУпАП) чи незаконного використання об'єктів права інтелектуальної власності (ст. 51-2 КУпАП) тощо.

Засобами відновлення $є$ адміністративно-правові інструменти, що виконують функцію поновлення порушених законних інтересів громадян у сфері власності, відновлення порядку володіння, користування та розпорядження майном. Ці засоби можуть стосуватися забезпечення примусового виконання обов'язків посадових осіб органів влади, відновлення правового становища громадян у сфері власності, що існувало до винесення незаконного рішення суб'єктом владних повноважень у цій сфері. Наприклад, відповідно дост. 166 та ст. 208 КАСУ судді в адміністративних справах місцевих загальних, окружних та апеляційних адміністративних судів уповноважені приймати окремі ухвали з метою забезпечення усунення в місячний строк причин та умов, що сприяли порушенням закону, які будуть виявлені під час здійснення правосуддя, в організаційно-правозастосовчій діяльності відповідних суб'єктів владних повноважень.

Важливим кроком на шляху оптимізації адміністративно-правового захисту законних інтересів громадян у сфері власності є активізація процесу використання засобів громадського контролю (діяльності громадських рад при органах влади; громадських інспекцій; громадських слухань та обговорень проєктів правових актів органів влади; громадських експертиз тощо).

\section{Висновки}

Загалом адміністративно-правові засоби захисту законних інтересів громадян у сфері власності $є$ опосередкованою ланкою у зв'язку з метою та результатами захисту. Саме їхня ефективність є основним мірилом гарантованості законних інтересів у суспільстві, а здатність втілюватися у правовій діяльності суб'єктів захисту свідчить про бажану близькість між метою і результатом захисту. Сучасна правова політика повинна виходити з науково обгрунтованої єдиної довгострокової стратегії правових реформ, спрямованих на посилення захисту законних інтересів громадян у сфері власності, забезпечення відкритості діяльності органів влади, які є суб'єктами захисту законних інтересів громадян у сфері власності, оптимізації системи органів, наділених повноважен- 
нями у цій сфері, підвищення рівня свідомості громадян та професійної етики посадових осіб, що володіють відповідними повноваженнями.

\section{Мітература}

1. Сабикенов С. Н. Об объективном характере интересов в праве. Советское государство и право. 1981. № 6. С. 34-41.

2. Рішення у справі за конституційним поданням 50 народних депутатів України щодо офіційного тлумачення окремих положень частини першої статті 4 Цивільного процесуального кодексу України (справа про охоронюваний законом інтерес) : Рішення Конституційного Суду України № 18-рп/2004 від 01.12.2004. Обічійний вiсник Украӥни. 2004. № 50. Ст. 67.

3. Малько А.В., Субочев В. В., Шериев А. М. Права, свободы и законные интересы: проблемы юридического обеспечения. Москва. : Норма : ИНФРА-М, 2010. $192 \mathrm{c}$.

4. Рабінович П. М. Основи загальної теорії права та держави Київ, 1994. 236 с.

5. Онуфрієнко О. В. Правові засоби у контексті інструментальної теорії права : автореф. дис. на здобуття наук. ступеня канд. юрид. наук : спец. 12.00.01 «Теорія та історія держави і права; історія політичних і правових вчень». Харків, 2004. 18 c.

THE PROBLEM OF PROT OF LEGITIMATE INTERESTS OF UKRAINIAN GITIZENS IN THE PROPERTY FIELD BY MEANS OF ADMINISTRATIVE LAW

The article is devoted to the analysis of legitimate interests of citizens of Ukraine in the field of property, identifying the specifics of their protection by administrative law, finding ways to form a system of effective means of administrative and legal protection of these legal opportunities, implementation of legal reforms in this area.

Particular attention is paid to substantiating the legal nature of the category of "le- gitimate interest", administrative and legal means and means of its protection. Analysis of the activities of subjects of protection of legitimate interests of citizens in the field of property, identification of specifics of public administration in this area, formation of an effective legislative model of administrative and legal regulation of public relations in the field of protection of legal opportunities for citizens to own, use and dispose of property.

The purpose of the article is a scientific analysis of the problem of administrative and legal protection of legitimate interests of citizens in the field of property by administrative law, substantiation that administrative legislation and administrative law play a key role in protecting the legitimate interests of citizens of Ukraine in property.

The scientific novelty of the article is manifested in the fact that it provides a comprehensive topical analysis of the formation of an effective legislative model of administrative and legal regulation of public relations in the field of protection of legal capacity of citizens to own, use and dispose of property. The analysis of activity of subjects of protection of lawful interests of citizens in the field of property has received further development.

Particular attention is paid to determining the features of the system of administrative and legal protection of the legitimate interests of citizens in the field of property.

The types of means of administrative and legal protection of legitimate interests of citizens in the sphere of property, which form the corresponding system, are comprehensively reflected.

It was found that the means of administrative and legal protection reflect the practical side of legal procedures, provide a real solution to problematic issues related to the legitimate interests of citizens to own, use and dispose of property, and help meet the needs related to the acquisition and preservation of objects property rights.

It is established that the external manifestation of the methods of administrative and legal protection of the legitimate interests of citizens in the field of property are the procedures enshrined in regulations. 


\section{Адміністративне право}

\section{АНОТАЦІЯ}

Стаття присвячена аналізу законних інтересів громадян України у сбері власності, виявленню специфіки їхнвого захисту засобами адміністративного права, пошуку шляхів формування системи ефбективних засобів адміністративно-правового захисту иих правових можливостей громадян, здійснення правових реборм у иій сббері. Особлива увага присвячена обгрунтуванню правової природи категорї «законний інтерес», адміністративно-правових способів та засобів його захисту. Дістав подальший розвиток аналіз діяльності суб'єктів захисту законних інтересів громадян у сбері власності, специбіки публічного управління у иій сфері, формування ефбективної законодавчої моделі адміністративно-правового регулювання суспільних відносин у сфері захисту правових можливостей громадян шодо володіння, користування та розпорядження майном.

Ключові слова: законний інтерес, право, адміністративно-правовий засіб, право власності, захист законних інтересів громадян у сбері власності, органи публічного управління, адміністративна відповідальність.
An important step towards optimizing the administrative and legal protection of the legitimate interests of citizens in the field of property is to intensify the process of using means of public control and.

The creation of such a legal basis is not yet complete and requires a theoretical basis that determines the specifics of the system of administrative and legal means of crime prevention in the financial sector in Ukraine.

Key words: legitimate interest, law, administrative-legal remedy, property right, protection of legitimate interests of citizens in the sphere of property, public administration bodies, administrative responsibility. 